\title{
Sulfur output by the 2014-15 flood lava eruption at Holuhraun, N-Iceland
}

\author{
THOR THORDARSON ${ }^{1}$ \\ ${ }^{1}$ Faculty of Earth Sciences, University of Iceland, Iceland \\ (*correspondence: torvth@hi.is)
}

The empirical method of Thordarson et al [1] for estimating sulfur emission from basaltic eruptions in Iceland was established using data from melt inclusion and groundmass glass from from eruptions in the past. It uses the relationships between $\mathrm{TiO}_{2} / \mathrm{FeO}$ and initial and residual sulfur (S) contents in melts, to establish pre- and post-eruptive $\mathrm{S}$ contents and reconstruct the $\mathrm{SO}_{2}$ emissions of a basaltic eruption. The 2014-15 tholeiite basalt flood lava eruption at Holuhraun in north central Iceland provided the opportunity to test and validate this empirical method. In both cases it was used to estimate the total atmospheric $\mathrm{SO}_{2}$-loading as well as the daily $\mathrm{SO}_{2}$ flux by the eruption.

The 2014-2015 Holuhraun eruption was an archetypical Icelandic eruption and the largest of its kind by volume in Iceland since the Laki event in 1783-4. It discharged $\sim 1.2$ $\mathrm{km}^{3}$ of lava and featured a 1-4 km-high, gas-charged eruption plume that produced significant volcanic pollution across Iceland. We obtain $\mathrm{TiO}_{2} / \mathrm{FeO}=0.156$ from EPMA analysis of groundmass glass in tephra grains giving a calculated initial $\mathrm{S}$ content of $1420 \mathrm{ppm}$ and residual S content of $435 \mathrm{ppm}$ for the 2014-15 magma. These values compare well with measured melt inclusion values of $1400 \mathrm{ppm} \mathrm{S}$ (= initial S content) and groundmass values of $425 \mathrm{ppm} \mathrm{S} \mathrm{(=} \mathrm{residuals}$ after vent degassing). The calculated residual $\mathrm{S}$ content after lava degassing is $180 \mathrm{ppm}$. These values indicate that the 2014-15 magma carried about 9 million tons (MT) of $\mathrm{SO}_{2}$ towards the surface. Of that $6.4 \mathrm{MT} \mathrm{SO}_{2}(\sim 70 \%)$, or $5.3 \mathrm{MT}$ $\mathrm{SO}_{2}$ per $\mathrm{km}^{3}$ of magma erupted, are estimated to have been released into the atmosphere above the vents and about 1.15 $\mathrm{MT} \mathrm{SO}_{2}(13 \%)$ were released from the lava. The average daily atmospheric $\mathrm{SO}_{2}$ mass burden, obtained using the calculated $\mathrm{SO}_{2}$ emissions in conjunction with estimated diurnal magma mass eruption rates, is $53 \pm 8$ kilo-tons (kt) for September 2014, which compares favorably with satellitederived average daily $\mathrm{SO}_{2}$ mass burdens of $99 \pm 49$ /day and $61 \pm 18 \mathrm{kt} /$ day during the same time period.

[1] Thordarson T, et al., 2003. Sulphur release from flood lava eruptions in the Veidivötn, Grímsvötn and Katla volcanic systems, Iceland. In: C. Oppenheimer, D.M. Pyle and J. Barclay (Editors), Volcanic Degassing. Geol Soc London, Spec Publ 213, pp. 103-121. 